\title{
Bone Morphogenetic Protein 4
}

National Cancer Institute

\section{Source}

National Cancer Institute. Bone Morphogenetic Protein 4. NCI Thesaurus. Code C95043.

Bone morphogenetic protein 4 (408 aa, $\sim 47 \mathrm{kDa}$ ) is encoded by the human BMP4 gene.

This protein is involved in the mediation of bone, cartilage, tooth and limb development. 